\title{
A Extradição no Alvorecer do Século XXI²
}

\author{
Florisbal de Souza Del'olmo
}

\section{RESUMO}

A presente tese se ocupa e analisa história, conceito, requisitos, importância, objeto, limites, fontes e classificação da extradição, bem como a experiência desse instituto no Brasil. A sociedade contemporânea, a partir da Paz da Vestfália, é estudada, por indispensável para as reflexões, de vez que é no contexto dessa sociedade que a extradição atua. Tal é o conteúdo da primeira parte da pesquisa. Ocupa-se, em seguimento, dos desafios que se antepócm à extradição no alvorecer do século XXI, desde novos fatores, como os gerados pelos governos e pela agressão aos direitos humanos, até novas formas assumidas pelo crime e adaptações do Direito Penal ao processo vivenciado na atualidade. Inserem-se investigações sobre crime dito organizado, contra a ordem econômica, de lavagem de dinheiro, de terrorismo e de tráfico de pessoas $\mathrm{c}$ de órgãos humanos. A terceira parte da tese, por fim, procura oferecer visões do instituto da extradição enquanto respostas aos novos desafios enfrentados pela sociedade contemporânea, privilegiando a abordagem sobre a cooperação entre os Estados - com novas perspectivas após o caso Pinochet - e o

${ }^{2}$ A banca foi composta pelo Professor Doutor José Francisco Rezek, Professor Titular da Universidade de Brasília e Doutor en Direito Público pela Faculdade de Direiro da Universidade de Paris; pelo Professor Doutor Antonio Celso Alves Pereira, Professor Livre-Docente em Direito Internacional Público pela Universidade do Estado do Rio de faneiro e Doutor em Dircito pela Universidade Federal do Rio de Janeiro, pela Professora Doutora Nádia de Araújo, Professora da Pontificia Universidade Católica do Rio de Janeiro e Doutora em Direito pela Universidade de São Paulo; pelo Professor Doutor Adherbal Meira Mattos, Professor Titular da Universidade Federal do Pará e Livre-Docente da Universidade Federal do Pará; e pelo Professor Doutor Cezar Saldanha Souza Junior, Professor Tinular da Universidade Federal do Rio Grande do Sul e Doutor em Direito pela Universidade de São Paulo. A referida defesa foi presidida pela Professora Doutora Cláudia Lima Marques, Professora Titular da Universidade Federal do Rio Grande do Sul e Doutora em Direito pela Universidade de Heidelberg - Alemanha, orientadora do referido trabalho. 
combate à impunidade; sobre a contribuição do Tribunal Penal Internacional, que materializa a existência de una corte criminal supranacional permanente; e sobre a experiência de códigos-modelo no campo penal e processual penal, ao lado de ações da Organização das Nações Unidas na luta contra a delinqüência internacional, sendo apresentada, inclusive, uma sugestão de Declaração da ONU no âmbito do combate internacional cooperativo contra a criminalidade sem fronreiras. 